\title{
Molecular Basis of Evolved Resistance to Glyphosate and Acetolactate Synthase-Inhibitor Herbicides in Kochia (Kochia scoparia) Accessions from Montana
}

\author{
Vipan Kumar, Prashant Jha, Darci Giacomini, Eric P. Westra, and Philip Westra*
}

\begin{abstract}
The rapid evolution and spread of glyphosate-resistant (GR) kochia in the Northern Great Plains is an increasing threat to GR cropping systems and conservation tillage practices common in this region. GR kochia accessions with 4.6- to 11 -fold levels of resistance to glyphosate have recently been reported in Montana. Those GR kochia accessions were also suspected to be resistant to acetolactate synthase (ALS) inhibitors, i.e., multiple herbicide-resistant (MHR) kochia. In this research, the level of resistance to the ALS-inhibitor herbicides (sulfonylureas) and the molecular mechanisms conferring resistance to glyphosate and ALS-inhibitor herbicides in MHR kochia was investigated. On the basis of whole-plant dose-response assays, MHR kochia accessions (GIL01, JOP01, and CHES01) were 9.3- to 30-fold more resistant to premixed thifensulfuron methyl + tribenuron methyl + metsulfuron methyl than the susceptible (SUS) accession. In an in vivo leaf-disk shikimate assay, MHR plants accumulated less shikimate than the SUS plants at a discriminate dose of $100 \mu \mathrm{M}$ glyphosate. Sequencing of the conserved region of EPSPS revealed no target-site mutation at $\mathrm{Thr}_{102}$ or Pro $_{106}$ residue. MHR kochia accessions had increased relative EPSPS gene copies $(\sim 4$ to 10$)$ compared with the SUS accession (single copy). Furthermore, MHR kochia accumulated higher EPSPS protein compared with the SUS plants. Resistance to the ALS-inhibitor herbicides was conferred by Pro $_{197}$ amino acid substitution (proline to glutamine). EPSPS gene amplification and a single target-site mutation at Pro $_{197}$ in $A L S$ gene confer resistance to glyphosate and ALS-inhibitor herbicides, respectively, in MHR kochia accessions from Montana. This is the first confirmation of occurrence of MHR kochia in Montana.
\end{abstract}

Nomenclature: Glyphosate; metsulfuron methyl; thifensulfuron methyl; tribenuron methyl; Kochia, Kochia scoparia (L.) Schrad.

Key words: ALS gene mutation, ALS-inhibitor resistance, EPSPS gene amplification, glyphosate resistance, multiple herbicide resistance.

Glyphosate is a systemic, nonselective, POST herbicide widely used for weed control in cropland and noncropland worldwide. Glyphosate has been described as a once-in-a-century herbicide because of its broad-spectrum efficacy on weeds, low mammalian toxicity, and environmentally benign nature (Duke and Powles 2008). Glyphosate inhibits the biosynthesis of aromatic amino acids (phenylalanine, tyrosine, and tryptophan) by inhibiting the 5-enolpyrovylshikimate-3-phosphate synthase (EPSPS; EC 2.5.1.19) enzyme in the shikimate pathway in plants, ultimately causing growth inhibition and plant death (Duke and Powles 2008; Powles 2010). Glyphosate usage has increased dramatically after the introduction of

DOI: 10.1614/WS-D-15-00021.1

* First and second authors: Ph.D. Student and Assistant Professor, Southern Agricultural Research Center, 748 Railroad Highway, Montana State University, Huntley, MT 59037; third, fourth, and fifth authors: Ph.D. students and Professor, Department of Bioagricultural Sciences and Pest Management, 1177 Campus Delivery, Colorado State University, Fort Collins, CO 80523. Corresponding author’s E-mail: pjha@montana.edu glyphosate-resistant (GR) crops in mid-1990s. In addition, this led to an increased adoption of conservation tillage by growers (Powles 2010). The exclusive use of glyphosate for weed control in GR cropping systems has been reported, with multiple applications per growing season (Norsworthy et al. 2007). Nevertheless, the increased selection pressure from glyphosate in GR crops resulted in evolution of GR weed biotypes. To date, glyphosate resistance has been reported in 31 weed species globally (Heap 2015).

Kochia, a monoecious $\mathrm{C}_{4}$ diploid $(2 \mathrm{n}=18)$, is among the most problematic summer annual broadleaf weeds in the Northern Great Plains (NGP) of the United States, including Montana (Eberlein and Fore 1984; Forcella 1985; Friesen et al. 2009). Kochia possesses unique biological attributes, including early seedling emergence, rapid growth, tolerance to abiotic stresses (heat, salt, drought), prolific seed production $(>50,000$ seeds plant $^{-1}$ ), low seed dormancy (1 to $2 \mathrm{yr}$ ), and longdistance seed dispersal by the tumble behavior of the 
mature plants (Baker et al. 2010; Christoffoleti et al. 1997; Friesen et al. 2009; Schwinghamer and Van Acker 2008). Furthermore, the protogynous nature of kochia flowering enforces a high degree of outcrossing and pollen-mediated gene flow (Mengistu and Messersmith 2002; Stallings et al. 1995). Consequently, there is a high genetic diversity within and among kochia populations (Stallings et al. 1995). All these biological traits make kochia a difficult-to-control weed species, with rapid development and spread of herbicide resistance. Kochia has evolved resistance to several herbicide mechanisms of action, including photosystem II inhibitors (atrazine), acetolactate synthase (ALS) inhibitors (sulfonylurea and imidazolinone herbicides), and synthetic auxins (dicamba and fluroxypyr) in the NGP (Heap 2015). In 2007, kochia accessions resistant to glyphosate were first detected in Kansas (Waite et al. 2013). Since then, GR kochia has emerged in nine other states in the NGP, including Montana, and in three provinces of Canada (Beckie et al. 2013; Heap 2015; Kumar et al. 2014). The increased occurrence of GR kochia is a potential threat to GR cropping systems such as corn (Zea mays L.), soybean [Glycine max (L.) Merr.], and sugar beet (Beta vulgaris L.), and to notill wheat (Triticum aestivum L.)-fallow rotation common in this region.

Five major mechanisms of glyphosate resistance have been characterized in weed species so far, e.g., target-site EPSPS mutation, EPSPS gene amplification, active vacuolar sequestration, reduced translocation, and rapid necrosis response (Sammons and Gaines 2014). EPSPS gene amplification is a novel mechanism of glyphosate resistance, first documented in Palmer amaranth (Amaranthus palmeri S. Wats.) (Gaines et al. 2010). Increased EPSPS gene copies in GR Palmer amaranth was positively correlated with EPSPS protein abundance (Gaines et al. 2010). This resistance mechanism has also emerged in other GR weed species, such as tall waterhemp [Amaranthus tuberculatus (Moq.) Sauer] (Lorentz et al. 2014; Tranel et al. 2011), spiny amaranth (Amaranthus spinosus L.) (Nandula et al. 2014), and Italian ryegrass [Lolium perenne ssp. multiflorum (Lam.) Husnot] (Salas et al. 2012). Reduced absorption or translocation has not been associated with glyphosate resistance in GR kochia in the U.S. Great Plains (Waite et al. 2013; Wiersma et al. 2015).

ALS-inhibitor-resistant kochia is widely spread across Montana and other NGP states, primarily through the selection of mutations in the ALS gene
(Heap 2015; Primiani et al. 1990). In particular, three highly conserved amino acids ( Pro $_{197}$, Asp $_{376}$, and $\left.\operatorname{Trp}_{574}\right)$ in the ALS enzyme are sensitive to alteration by recurrent selection from ALS-inhibitor herbicides in kochia (Beckie et al. 2013; Tranel and Wright 2002; Tranel et al. 2015). An alteration in any of these amino acids confers a high level of resistance to sulfonylurea or imidazolinone herbicides in kochia (Tranel and Wright 2002; Tranel et al. 2015).

Winter-wheat-fallow rotation dominates $>90 \%$ of the dryland cropping systems of this region, including Montana. The average precipitation in Montana is $<30 \mathrm{~cm}$, which is often a limiting factor for continuous cropping. The purpose of chemical fallow in wheat-fallow rotation is to prevent soil erosion and to conserve soil moisture for successful establishment of winter wheat planted in the fall (Lenssen et al. 2007). Glyphosate is the most commonly used herbicide to control kochia and other weeds in chemical fallow or in postharvest wheat stubble (Donald and Prato 1991; Kumar and Jha 2015a,b), and a typical chemical-fallow field receives three to four applications of glyphosate $\left(0.870 \mathrm{~kg}\right.$ ae ha $\left.{ }^{-1}\right)$ before planting of winter wheat in a year. Because of enhanced selection pressure from repeated use of glyphosate, GR kochia accessions with 4.6- to 11-fold levels of resistance to glyphosate have evolved in wheat-fallow fields in northern Montana (Kumar et al. 2014). With historical reports on widespread occurrence of kochia resistant to ALS inhibitors in Montana and other adjoining states (Primiani et al. 1990; Sivakumaran et al. 1993), these confirmed GR kochia biotypes from Montana were also suspected to be resistant to ALS inhibitors (sulfonylurea), i.e., multiple herbicide-resistant (MHR) kochia. The objectives of this research were (1) to elucidate the mechanism conferring resistance to glyphosate and (2) to characterize the level of resistance to ALSinhibitor herbicides (sulfonylureas) and determine if target-site mutation(s) in ALS might confer resistance to ALS inhibitors in MHR kochia accessions from Montana.

\section{Materials and Methods}

Plant Material. Three GR kochia accessions (GIL01, JOP01, and CHES01) collected in fall of 2012 from chemical-fallow fields (wheat-fallow rotation) in Hill and Liberty counties of northern Montana were investigated. The glyphosatesusceptible (SUS) kochia accession was collected 
from a field used for long-term organic trials near Huntley, MT. Preliminary greenhouse doseresponse experiments indicated that the SUS population was susceptible to glyphosate and ALSinhibitor herbicides (data not shown). Plants from the dose-response study (Kumar et al. 2014) that survived at $1.68 \mathrm{~kg}$ ae ha ${ }^{-1}$ were transplanted into 5 -L plastic pots containing a commercial potting mix (VermiSoil ${ }^{\mathrm{TM}}$, Vermicrop Organics, 4265 Duluth Avenue, Rocklin, CA) in a greenhouse at the Montana State University Southern Agricultural Research Center (MSU-SARC) near Huntley, MT. The greenhouse was maintained at $25 / 23 \mathrm{C} \pm 3 \mathrm{C}$ day/night temperatures and 16/8-h day/night photoperiods supplemented with metal halide lamps $\left(400 \mu \mathrm{mol} \mathrm{m} \mathrm{m}^{-2} \mathrm{~s}^{-1}\right)$. Kochia plants were watered once daily to avoid moisture stress, and fertilized (Miracle-Gro water-soluble fertilizer [248-16], Scotts Miracle-Gro Products Inc., 14111 Scottslawn Road, Marysville, $\mathrm{OH}$ ) once a week to maintain good growth. Kochia plants $(60$ to $70 \mathrm{~cm}$ tall) were covered with pollen bags (DelStar Technologies, Inc., 601 Industrial Drive, Middletown, DE 19709) to avoid cross-pollination, and allowed to produce F1 seed. Two pollen bags (each of 50.8 by $45.7 \mathrm{~cm}$ size) were glued together lengthwise to fully cover each kochia plant. The F1 generation was selfed to obtain the F2 seed. Screening of F2 plants of the GR populations indicated that $>95 \%$ of individuals survived the $1.68 \mathrm{~kg} \mathrm{ha}^{-1}$ rate of glyphosate (data not shown). Similarly, F2 seeds of the SUS accession were obtained by selfing a group (to prevent inbreeding depression) of F1 plants under pollen isolation conditions as described previously, in a separate greenhouse. The F2 seeds of SUS and GR kochia accessions were used for subsequent experiments.

Shikimate Accumulation. Three plants per kochia accession (JOP01, GIL01, CHES01, and SUS) were tested for shikimate accumulation using an in vivo leaf-disk assay (Shaner et al. 2005). Three technical replicates (5-mm-diam leaf disks) from each young kochia plant (8 to $10 \mathrm{~cm}$ tall) per accession were sampled, and the assay was repeated in time. On the basis of preliminary experiments, $100 \mu \mathrm{M}$ glyphosate (discriminating dose) was chosen to differentiate the shikimate accumulation between GR and SUS kochia plants. The excised leaf disks were placed into the wells of a 96-well microtiter plate containing $7.7 \mathrm{mM}$ ammonium phosphate and glyphosate (molecular grade) at doses of 0,100 , or $1,000 \mu \mathrm{M}$. The samples were incubated in light for $16 \mathrm{~h}$ at room temperature, frozen $(-20 \mathrm{C})$ and thawed $(60 \mathrm{C})$, and subjected to the extraction procedure described by Shaner et al. (2005) and Wiersma et al. (2015). Shikimate levels were recorded at $380 \mathrm{~nm}$ on a 96-well plate reader (BioTek $^{\text {TM }}$ Synergy ${ }^{\mathrm{TM}} 2$ multi-mode microplate reader, Winooski, VT). A shikimate standard curve was developed to quantify shikimate accumulation (ng shikimate $\mu^{-1}$ ) in the experimental samples (Shaner et al. 2005). Experiments were conducted in a completely randomized design. Data were subjected to ANOVA using PROC MIXED in SAS 9.2 (SAS Institute, Inc., SAS Campus Drive, Cary, NC 27513). Means were separated using Fisher's Protected LSD test at $\mathrm{P}<0.05$. The interaction of experimental run with accession, glyphosate dose, or accession by glyphosate dose was nonsignificant; therefore, data were pooled over experimental runs.

\section{Sequencing of EPSPS Thr $\mathrm{T}_{102}$ and Pro ${ }_{106}$ Codons.}

Three plants from each kochia accession were sampled, and the experiment was repeated in time. A 100-mg sample of young leaf tissue was flash frozen with liquid nitrogen and ground to a fine powder. The genomic DNA (gDNA) extraction was performed using the Qiagen DNeasy Plant mini kit. The DNA quality and concentration was determined using a Bio-Rad SmartSpect ${ }^{\mathrm{TM}}$ Plus spectrophotometer. The conserved region of the EPSPS gene encompassing $\mathrm{Pro}_{106}$ and $\mathrm{Thr}_{102}$ codons was amplified by polymerase chain reaction (PCR). The primer set previously designed for Palmer amaranth EPSPS sequence (200 base pairs [bp]) was utilized (Gaines et al. 2010); the forward and reverse primer sequences were 5'-ATGTTGGACGCTCTCAGAACT-3' and 5'-TGAATTTC CTCCA GCAACGGC-3', respectively. Each PCR reaction contained $10 \mu \mathrm{l}$ of $\mathrm{GoTaq}^{\circledR}$ Green Master Mix (containing TaqDNA polymerase, deoxynucleotide triphosphates [dNTPs], $\mathrm{MgCl}_{2}$, and reaction buffers), $1 \mu$ l each of forward and reverse primers $(5 \mu \mathrm{M})$, and $5 \mu \mathrm{l}$ of gDNA $\left(2 \mathrm{ng} \mu^{-1}\right)$. The thermocycle conditions for PCR were: initial denaturation at $98 \mathrm{C}$ for $1 \mathrm{~min}$, followed by 30 cycles of denaturation at $98 \mathrm{C}$ for $15 \mathrm{~s}$, primer annealing at $50 \mathrm{C}$ for $30 \mathrm{~s}$, and product extension at $72 \mathrm{C}$ for $45 \mathrm{~s}$. A final extension cycle of $10 \mathrm{~min}$ at $72 \mathrm{C}$ was included, and the reaction was terminated and held at $4 \mathrm{C}$. PCR products were separated on $1 \%$ agarose gel, stained with ethidium bromide, and isolated from the gel using the GENECLEAN ${ }^{\circledR}$ II Kit (MP Biochemical ${ }^{\text {TM }}$ ) by following manufacturer's protocol. Sanger sequencing of purified PCR 
fragments was performed using an $\mathrm{ABI}^{\mathrm{TM}} 3130 \times \mathrm{L}$ genetic analyzer. CLC genomics workbench software was utilized to analyze the sequence reads, and the EPSPS sequence of kochia samples was aligned to a reference glyphosate-susceptible Palmer amaranth EPSPS sequence to determine substitutions at Pro $_{106}$ or $\mathrm{Thr}_{102}$ codon.

EPSPS Genomic Copy Number. Real-time quantitative PCR (qPCR) experiments on genomic DNA were performed to determine relative EPSPS: ALS genomic copy number in the kochia accessions tested. Three plants per accession were sampled. The ALS gene was chosen as a reference gene because of the stability of ALS gene expression across kochia populations (Wiersma et al. 2015). For all samples, the $A L S$ plant $1: A L S$ plant 2 relative gene copy number was equal to 1 , also reported by Wiersma et al. (2015). The gDNA extracted for EPSPS gene sequencing was used for determining the gene copy number because of its high quality (260/280 ratio of $\geq 1.8)$. Primer sequences specific to kochia EPSPS and ALS gene were similar to those previously reported (Wiersma et al. 2015). The primer set for the EPSPS gene (EPSPF1: 5'-GGC CAA AAGGGCAATCGTGGAG-3' and EPSPR1: 5' -CATTGCCGTTCCCGCGTTTCC-3') produced an approximately 102-bp product, and the ALS primer set (ALSF1: 5'-ATGCAGA CAA TGTTGGATAC-3' and ALSR1: 5'-TCAACCATCG ATA CGAACAT-3') amplified 159-bp PCR products. Each qPCR reaction contained $2 \mu \mathrm{l}$ of gDNA $\left(2 \mathrm{ng} \mathrm{\mu l}^{-1}\right)$ template, $1 \times$ Perfecta SYBR Green Supermix, and $250 \mathrm{nM}$ each of forward and reverse primers (Giacomini et al. 2014). Each qPCR reaction was performed with a final reaction volume of $12.5 \mu \mathrm{l}$ on a 96-well PCR plate. The qPCR thermo profiles were: $95 \mathrm{C}$ for $15 \mathrm{~min}, 40$ cycles of $95 \mathrm{C}$ for $30 \mathrm{~s}$, and $60 \mathrm{C}$ for $1 \mathrm{~min}$, followed by melt-curve analysis. Negative controls containing $10 \mu \mathrm{l}$ of Mastermix, $250 \mathrm{nM}$ each of forward and reverse primers, and $2.5 \mu \mathrm{l}$ of high-performance liquid chromatography water with no gDNA template were also included. Standard curves for each primer pair were developed using a 10-fold serial dilution of the genomic DNA, and primer efficiency was $102 \%$ for EPSPS and $101 \%$ for $A L S$. Threshold cycles $\left(C_{\mathrm{t}}\right)$ were recorded by the Bio-Rad CFX96 $^{\text {TM }}$ Real Time System C 1000 Touch $^{\text {TM }}$ thermal cycler. The qPCR reaction efficiency was $102 \%$ ( $R^{2}$ of 0.99 and a slope of -3.215 ). There was a linear relationship between $C_{\mathrm{t}}$ values and $\log$ DNA concentration, indicating that the $C_{\mathrm{t}}$ values were a reliable estimate of the relative EPSPS gene copy number. The relative EPSPS gene copy number was calculated as $2^{-\Delta C \mathrm{t}}$, where $\Delta C_{\mathrm{T}}=C_{\mathrm{t}}$, EPSPS $-C_{\mathrm{t}}$, ALS (Gaines et al. 2010). Each sample was run in triplicate to calculate the mean and standard error of the increase in relative EPSPS copy number. Correlation analysis between relative EPSPS copy number and shikimate accumulation or glyphosate resistance level $(50 \%$ growth inhibition $\left[I_{50}\right]$ or $50 \%$ shoot dry weight reduction $\left[\mathrm{GR}_{50}\right]$ values) was performed using PROC CORR in SAS 9.2.

EPSPS Protein Abundance. To further confirm the EPSPS gene amplification in the GR kochia accessions, the relative abundance of the EPSPS protein was determined using a western blot. A protein assay was conducted by following a previously established protocol (Bolt and Mahoney 1997) with slight modification. Three plants per kochia accession were sampled, and the experiment was repeated. Young leaf tissue $(100 \mathrm{mg})$ was ground to a fine powder in liquid nitrogen. Total protein was extracted using a $1: 4$ ratio of leaf tissue to laemmli buffer (10\% $\beta$-mercaptoethanol, $60 \%$ sodium dodecyl sulfate [SDS] [10\% w/v], 20\% glycerol, $10 \% \mathrm{H}_{2} \mathrm{O}$ ). Protein samples were then boiled for $5 \mathrm{~min}$ and centrifuged for $5 \mathrm{~min}$ at $16,900 \times g$. Total protein in $15-\mu$ l aliquots were loaded in each lane and resolved by $10 \%(\mathrm{w} / \mathrm{v})$ SDS-polyacrylamide gel electrophoresis at $25 \mathrm{~mA}$ per gel for $1 \mathrm{~h}$. Gel was stained with Ponceau $S$ before the membrane transfer to visually confirm that each lane had the same amount of protein loaded. Protein of each sample was transferred to nitrocellulose membrane (Osmonics Nitrobind nitrocellulose transfer membranes, GE Water and Process Technologies, 4636 Somerton Road, Feasterville-Trevose, PA 19053) at $300 \mathrm{~mA}$ for approximately $1 \mathrm{~h}$. The nitrocellulose membrane was blocked for $12 \mathrm{~h}$ at $4 \mathrm{C}$ in TBST $(20 \mathrm{mM}$ Tris base [pH 7.5], 0.5 M NaCl, 0.05\% Tween-20) (SigmaAldrich Co. LLC., 3050 Spruce Street, St. Louis, MO 63103) containing 5\% milk powder. Membrane was incubated at $20 \mathrm{C}$ for $1 \mathrm{~h}$ with primary EPSPS antibody (Monsanto Co., St. Louis, MO) that was diluted $1: 2,000$ in TBST milk solution. Membrane was rinsed three times in TBST, and incubated at $20 \mathrm{C}$ for $1 \mathrm{~h}$ with secondary antibody (goat anti-rabbit) conjugated with horseradish peroxidase (ImmunoPure Antibody; Thermo Fischer) using a dilution of $1: 5,000$ in TBST milk solution. Membrane was again rinsed three 
times in TBST milk solution, and an activator 24 solution (SuperSignal West Pico chemiluminescent substrate from Thermo Fischer) was applied to the membrane to activate chemiluminescence. The protein bands (signals) were detected using a Bio-Rad ChemiDoc ${ }^{\text {TM }}$ XRS imager. One susceptible and two confirmed GR and Palmer amaranth accession from Georgia (Gaines et al. 2010) and a confirmed GR kochia accession from Colorado (Wiersma et al. 2015) were included for comparison (positive controls). The selected positive controls of the GR weeds were known to have high EPSPS protein abundance (Gaines et al. 2010; Wiersma et al. 2015), and were used for qualitative assessment of EPSPS protein in the GR vs. SUS kochia accessions tested.

\section{Whole-Plant Dose-Response for ALS-Inhibitor} Herbicide. Whole-plant dose-response experiments were conducted in the greenhouse at the MSUSARC near Huntley, MT to quantify the level of resistance to premixed thifensulfuron methyl $(27.30 \%$ by wt) + tribenuron methyl $(13.60 \%$ by wt + metsulfuron methyl $(10.90 \%$ by wt) (Ally ${ }^{\circledR}$ Extra SG, DuPont Company, Wilmington, DE 19898) in the GR kochia accessions (GIL01, JOP01, and CHES01), referred to as MHR, compared with the SUS accession. The experiment was conducted under similar growth conditions as previously described. Single kochia seedlings were transplanted into $10-\mathrm{cm}$-diam pots containing the same potting mix. Experiments were arranged in a randomized complete block design with eight replications (one plant per pot), and repeated two times. Actively growing 8- to $10-\mathrm{cm}$-tall kochia plants were sprayed with the premixed ALSinhibitor herbicide at doses of $0,0.0025,0.0045$, $0.009,0.018,0.036,0.072,0.144,0.288$, and $0.648 \mathrm{~kg}$ ai ha ${ }^{-1}$. Methylated seed oil at $1 \%(\mathrm{v} / \mathrm{v})$ was included. Herbicide applications were made inside a stationary cabinet spray chamber equipped with a flat-fan nozzle tip (TeeJet 8001XR, Spraying System Co., Wheaton, IL) calibrated to deliver $94 \mathrm{~L} \mathrm{ha}^{-1}$ of spray solution at $276 \mathrm{kPa}$. After the herbicide application, plants were returned to the greenhouse, watered daily to avoid moisture stress, and fertilized (as previously described). Kochia plants were harvested at the soil level at 3 wk after treatment and dried at $60 \mathrm{C}$ for $3 \mathrm{~d}$ to determine shoot dry weight $\left(\right.$ g plant $\left.^{-1}\right)$.

Shoot dry-weight data from the whole-plant dose-response experiments were subjected to ANOVA using PROC MIXED procedure in SAS.
Residual analyses were performed using PROC UNIVARIATE in SAS. Data were combined across experimental runs because of nonsignificant interaction of experimental run by treatment. Pooled data for each kochia accession were regressed over doses of premixed thifensulfuron methyl + tribenuron methyl + metsulfuron methyl herbicide using the four-parameter log-logistic model (Seefeldt et al. 1995)

$Y=C+\{D-C / 1+\exp [B(\log X-\log E)]\}$

where $Y$ refers to shoot dry weight (g plant $\left.{ }^{-1}\right), C$ is the lower limit, $D$ is the upper limit, $B$ is the slope, $E$ is the herbicide dose required for $50 \%$ reduction in shoot dry weight referred to as $\mathrm{GR}_{50}$, and $X$ is the herbicide dose. A lack-of-fit test showed the accuracy of the nonlinear model $(P=0.516)$. Parameter estimates, standard errors, and $\mathrm{GR}_{90}$ values (dose of the herbicide required for $90 \%$ reduction in shoot dry weight) of the dose-response curves were determined using the $d r c$ package in $R$ software (Knezevic et al. 2007). Resistance index (referred to as R/S ratio) for each kochia accession was estimated by dividing the $\mathrm{GR}_{50}$ value of a resistant accession by the $\mathrm{GR}_{50}$ value of the SUS accession.

ALS Gene Sequencing. The gDNA was extracted from three kochia plants per accession using the Qiagen DNeasy Plant mini kit, and the experiment was repeated. The quality and concentration of gDNA for each sample was determined using a BioRad SmartSpect Plus spectrophotometer. From previously published research (Beckie et al. 2013; Warwick et al. 2008), a primer set (ALSF1: 5' ATGGCGTCTACTG TGCAAATCCC-3' and ALSR1: 5'-AACTT GTTCTTCCA TCACCTTC G-3') was designed to amplify almost the entire ALS gene (1,800 bp). Each PCR reaction contained $8.75 \mu \mathrm{l}$ of $\mathrm{iTaq}^{\mathrm{TM}}$ DNA polymerase master mix (containing iTaq DNA polymerase, dNTPs, $\mathrm{MgCl}_{2}$, and reaction buffers), $0.5 \mu \mathrm{l}$ each of forward and reverse primers $(25 \mu \mathrm{M})$, and $2.5 \mu \mathrm{l}$ of DNA template (30 ng $\mu \mathrm{l}^{-1}$ ). PCR was performed using a Bio-Rad $\mathrm{T} 100^{\mathrm{TM}}$ thermal cycler under the following conditions: initial denaturation at $95 \mathrm{C}$ for $3 \mathrm{~min}, 30$ cycles of $30 \mathrm{~s}$ at $95 \mathrm{C}, 30 \mathrm{~s}$ at $66 \mathrm{C}$, and $90 \mathrm{~s}$ at $72 \mathrm{C}$ followed by $10 \mathrm{~min}$ at $72 \mathrm{C}$. The reaction was terminated and held at $4 \mathrm{C}$. The PCR fragment was purified using QIAquick PCR purification kit following the manufacturer's protocol. The Sanger sequencing of purified PCR fragments was performed. Samples were sequenced 
with the same primer set used for PCR amplification and another internal primer set (ALSF2: 5'GAC GGATGCTTTTCAG GAG-3' and ALSR2: 5'-TTGGCGAGGGTTTCTGTAC-3'). The sequence reads of experimental samples were analyzed using the MultAlin software, and aligned to a reference $A L S$ gene from SUS kochia. The aligned nucleotide sequences were analyzed for any mutation at the single nucleotide position. The derived amino acid positions were based on the amino acid sequence of the ALS gene in Arabidopsis (Sathasivan et al. 1990).

\section{Results and Discussion}

Shikimate Accumulation. No difference in shikimate accumulation was observed between the nontreated ( $0 \mu \mathrm{M}$ glyphosate) GR and SUS kochia accessions (Table 1). However, at a discriminate dose of $100 \mu \mathrm{M}$ glyphosate, the SUS kochia plants accumulated $19.83 \mathrm{ng}$ of shikimate $\mu^{-1}$, which was 6- to 17-fold higher than the shikimate accumulated by GR plants of JOP01, CHES01, and GIL01 accessions. No differences in shikimate accumulation were observed among kochia accessions at $1,000 \mu \mathrm{M}$ glyphosate (data not shown). Similarly, GR plants of Amaranthus species and Italian ryegrass accumulated less shikimate compared with the susceptible plants at a glyphosate dose of 100 $\mu \mathrm{M}$, and levels of shikimate did not differ between susceptible and GR plants at 500 and 1,000 $\mu \mathrm{M}$ glyphosate (Gaines et al. 2010; Nandula et al. 2008, 2012). Shikimate, a dephosphorylated substrate of the EPSPS enzyme, accumulates in plants when treated with glyphosate (Singh and Shaner 1998). This assay can reliably be used to confirm resistance to glyphosate, also reported for several other GR weed species (Gaines et al. 2010; Nandula et al. 2014; Shaner et al. 2005).

\section{Sequencing of EPSPS Thr $\mathrm{T}_{102}$ and Pro ${ }_{106}$ Codons.} In general, target-site mutation in GR weed species involves amino acid substitution at the Pro 106 position (proline to serine, threonine, alanine, or leucine) (Sammons and Gaines 2014). However, a field-evolved population of GR goosegrass [Eleusine indica (L.) Gaertn.] has recently been identified in Australia with a double mutation at $\mathrm{Thr}_{102}$ codon (threonine to isoleucine) and Pro $_{106}$ codon (proline to serine); which conferred a high level of glyphosate resistance in the GR goosegrass population (Yu et al. 2015). There was no point mutation at the Pro $_{106}$ residue of the derived amino acid sequences in any of the tested GR kochia accessions from Montana
Table 1. Shikimate accumulation in glyphosate-susceptible and glyphosate-resistant kochia accessions from Montana.

\begin{tabular}{lcc}
\hline & \multicolumn{2}{c}{ Shikimate accumulation $^{\mathrm{a}}$} \\
\cline { 2 - 3 } Accession $^{\mathrm{b}}$ & $0 \mu \mathrm{M}$ glyphosate & $100 \mu \mathrm{M}$ glyphosate \\
\cline { 2 - 3 } & & \\
SUS & $2.06 \mathrm{a}$ & $\mathrm{I}^{-1}$ \\
JOP01 & $2.21 \mathrm{a}$ & $19.83 \mathrm{a}$ \\
CHES01 & $1.79 \mathrm{a}$ & $3.91 \mathrm{~b}$ \\
GIL01 & $1.20 \mathrm{a}$ & $1.15 \mathrm{~b}$ \\
\hline
\end{tabular}

${ }^{a}$ Leaf disks ( $5 \mathrm{~mm}$ diam) were excised from young (8 to 10 $\mathrm{cm}$ tall) actively growing kochia plants, and accumulation of shikimate was determined by in vivo assay.

b Abbreviations: SUS, susceptible kochia accession, Huntley, MT; GIL01, glyphosate-resistant (GR) kochia accession from Gildford, MT; JOP01, GR kochia accession from Joplin, MT; CHES01, GR kochia accession from Chester, MT.

${ }^{\mathrm{c}}$ Means within the column followed by the same letters are not significantly different on the basis of Fisher's Protected LSD test at $\mathrm{P}<0.05$.

(Table 2). Furthermore, there was no mutation observed at the $\mathrm{Thr}_{102}$ codon in the 200-bp EPSPS sequence of GR kochia (Table 2). Sequence alignment of tested individuals with reference EPSPS sequence of Palmer amaranth exhibited similar consensus at $\mathrm{Pro}_{106}$ and $\mathrm{Thr}_{102}$ (Table 2). Therefore, amino acid substitution at the $\mathrm{Pro}_{106}$ or $\mathrm{Thr}_{102}$ codon of EPSPS can be ruled out as a possible mechanism of glyphosate resistance in the GR kochia populations tested in this research. Although mutation at the $\mathrm{Thr}_{102}$ position was not investigated, there was a lack of Pro ${ }_{106}$ mutation in the EPSPS gene in GR kochia populations from Kansas and Colorado (Wiersma et al. 2015). A lack of target-site mutation exists in GR populations of other weed species, such as Palmer amaranth and spiny amaranth (Gaines et al. 2010; Nandula et al. 2014).

EPSPS Genomic Copy Number. Results from the qPCR analysis revealed that plants of JOP01 accession had approximately 6 to 8, GIL01 had 4 to 9 , and CHES01 had 6 to 10 relative copies of the EPSPS gene (Figure 1). The relative EPSPS copy number varied among plants within a GR accession, which may be expected in kochia, a crosspollinated species with high level of genetic diversity (Mengistu and Messersmith 2002, Stallings et al. 1995). In contrast, all SUS kochia plants had only one relative EPSPS copy number. GR kochia accessions from Kansas and Colorado had three to eight relative EPSPS: ALS genomic copy numbers (Wiersma et al. 2015). EPSPS gene amplification (increased copy number) is a novel mechanism of resistance to glyphosate, also reported in other GR 
Table 2. Nucleotide bases and derived amino acid sequence in the conserved region of the EPSPS gene from glyphosate-susceptible and glyphosate-resistant kochia accessions from Montana. The bold nucleotide codons encoded $\mathrm{Thr}_{102}$ and Pro $_{106}$ residues. $^{\mathrm{a}}$

\begin{tabular}{|c|c|c|c|c|c|c|c|c|c|c|c|}
\hline $\begin{array}{l}\text { Reference EPSPS } \\
\text { gene sequence of } \\
\text { Palmer amaranth } \\
\text { Amino acid positions } \\
\end{array}$ & $\begin{array}{c}\text { GGA } \\
\text { Gly } \\
101\end{array}$ & $\begin{array}{c}\text { ACG } \\
\text { Thr } \\
102 \\
\end{array}$ & $\begin{array}{c}\text { GCA } \\
\text { Ala } \\
103\end{array}$ & $\begin{array}{c}\text { ATG } \\
\text { Met } \\
104\end{array}$ & $\begin{array}{c}\text { CGC } \\
\text { Arg } \\
105\end{array}$ & $\begin{array}{c}\text { CCA } \\
\text { Pro } \\
106\end{array}$ & $\begin{array}{c}\text { TTG } \\
\text { Leu } \\
107\end{array}$ & $\begin{array}{c}\text { ACA } \\
\text { Thr } \\
108\end{array}$ & $\begin{array}{c}\text { GCT } \\
\text { Ala } \\
109\end{array}$ & $\begin{array}{c}\text { GCA } \\
\text { Ala } \\
110\end{array}$ & $\begin{array}{c}\text { GTT } \\
\text { Val } \\
111\end{array}$ \\
\hline SUS1 & GGA & ACG & GCA & ATG & CGC & CCA & TTG & ACA & GCT & GCA & GTT \\
\hline SUS2 & GGA & ACG & GCA & ATG & CGC & CCA & TTG & ACA & GCT & GCA & GTT \\
\hline SUS3 & GGA & ACG & GCA & ATG & CGC & CCA & TTG & ACA & GCT & GCA & GTT \\
\hline JOP011 & GGA & ACG & GCA & ATG & CGC & CCA & TTG & ACA & GCT & GCA & GTT \\
\hline JOP012 & GGA & ACG & GCA & ATG & CGC & CCA & TTG & ACA & GCT & GCA & GTT \\
\hline JOP013 & GGA & ACG & GCA & ATG & CGC & CCA & TTG & ACA & GCT & GCA & GTT \\
\hline GIL011 & GGA & ACG & GCA & ATG & CGC & CCA & TTG & ACA & GCT & GCA & GTT \\
\hline GIL012 & GGA & ACG & GCA & ATG & CGC & CCA & TTG & ACA & GCT & GCA & GTT \\
\hline GIL013 & GGA & ACG & GCA & ATG & CGC & CCA & TTG & ACA & GCT & GCA & GTT \\
\hline CHES011 & GGA & ACG & GCA & ATG & CGC & CCA & TTG & ACA & GCT & GCA & GTT \\
\hline CHES012 & GGA & ACG & GCA & ATG & CGC & CCA & TTG & ACA & GCT & GCA & GTT \\
\hline CHES013 & GGA & ACG & GCA & ATG & CGC & CCA & TTG & ACA & GCT & GCA & GTT \\
\hline
\end{tabular}

a Abbreviations: SUS1, SUS2, and SUS3, three kochia plants from glyphosate-susceptible (SUS) accession; JOP011, JOP012, and JOP013, three kochia plants from glyphosate-resistant (GR) JOP01 accession; GIL011, GIL012, and GIL013, three kochia plants from GR GIL01 accession; CHES011, CHES012, and CHES013, three kochia plants from GR CHES01 accession.

weed species. For instance, GR Palmer amaranth had high relative EPSPS gene copies of 40 to 100 in populations from Georgia (Gaines et al. 2010), 20 to 60 in populations from North Carolina (Chandi et al. 2012), and 33 to 59 in populations from Mississippi (Ribeiro et al. 2014). GR spiny amaranth from Mississippi had 26 to 37 copies, and Italian ryegrass from Arkansas had 15 to 25 relative copies of the EPSPS gene (Nandula et al. 2014; Salas et al. 2012). However, lower folds of EPSPS gene amplification (2- to 10-fold) have been reported in GR Palmer amaranth accessions from New Mexico (Mohseni-Moghadam et al. 2013). The range of relative EPSPS gene copies (4 to 10) observed in GR kochia accessions from Montana

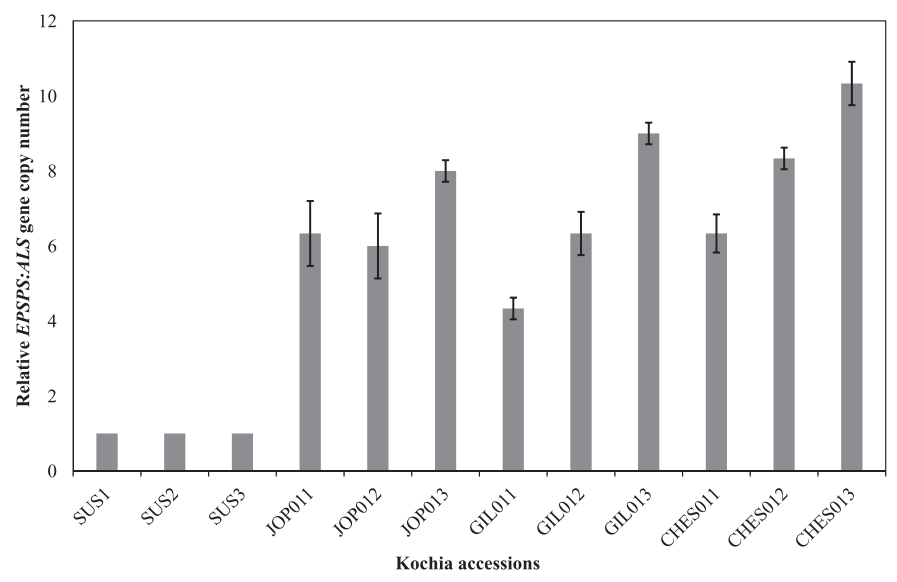

Figure 1. Relative EPSPS genomic copy number in glyphosateresistant (JOP01, GIL01, and CHES01) and susceptible (SUS) kochia accessions from Montana. Vertical bars represent standard error of mean $(n=6)$. was comparable with the range (three to eight relative EPSPS copies) reported recently in GR kochia accessions from Kansas and Colorado (Wiersma et al. 2015), and also with that observed in GR tall waterhemp (two to eight copies) (Lorentz et al. 2014).

\section{Correlation of EPSPS Gene Copy Number with} Glyphosate Resistance. The EPSPS gene copy number of SUS and GR kochia plants was correlated with the shikimate accumulation at the discriminating dose of glyphosate (Figure 2). The SUS plants with one relative EPSPS copy had higher shikimate accumulation compared with the GR kochia plants with 4 to 10 relative EPSPS copies. These results further support the hypothesis of overproduction of the EPSPS enzyme from increased copies of the EPSPS gene produced by GR kochia plants, thus allowing them to tolerate lethal doses $\left(>1.26 \mathrm{~kg}\right.$ ae ha $\left.{ }^{-1}\right)$ of glyphosate.

The $I_{50}$ and $\mathrm{GR}_{50}$ values (Figure 3) were obtained from our previously reported whole-plant dose-response curves of the selected GR and SUS accessions (Kumar et al. 2014). A strong positive linear relationship was observed between $I_{50}$ and EPSPS gene copy number $(r=0.92)$ (Figure 3a), and between $\mathrm{GR}_{50}$ and EPSPS gene copy number $(r=0.86)$ (Figure $3 \mathrm{~b})$. This further suggests that 4to 10-fold increased EPSPS gene copy numbers resulted in 4.6- to 11-fold levels of resistance (based on resistance index [R/S ratio]) to glyphosate in selected GR kochia accessions from Montana. It is 


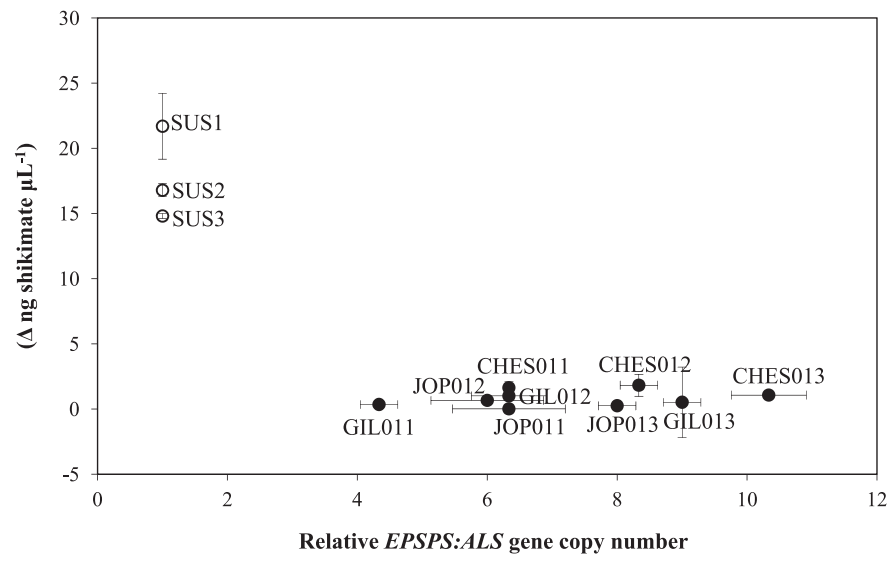

Figure 2. Correlation of relative EPSPS genomic copy number vs. shikimate accumulation in glyphosate-resistant (JOP01, GIL01, and CHES01) and susceptible (SUS) kochia accessions from Montana. Shikimate accumulation was measured after incubation of samples in $100 \mu \mathrm{M}$ glyphosate in an in vivo leafdisk assay. The $\Delta$ ng shikimate $\mu l^{-1}$ was calculated as the difference in shikimate accumulation between treated and untreated plants. Error bars indicate standard error.

likely that increase in selection pressure from glyphosate may select GR kochia individuals with higher copies of the EPSPS gene, conferring higher levels of glyphosate resistance.

EPSPS Protein Abundance. A representative image of EPSPS protein abundance of the tested kochia accessions (SUS vs. GIL01, JOP01, and CHES01) is presented in Figure 4. The protein assay with polyclonal anti-EPSPS antibody using western blot indicated that the GR kochia accessions from Montana had higher EPSPS protein abundance compared with the SUS kochia accession. To elaborate, the three GR kochia accessions (lanes 2, 3, and 4, respectively) with 4 to 10 relative copies of the EPSPS gene showed intense EPSPS protein signal, and the signal saturated at a molecular weight of $48 \mathrm{kDa}$ (Figure 4). No signal was detected in lane 1 containing the SUS kochia accession. A comparable signal of the EPSPS protein extract was observed in a GR kochia accession (GR-CO) from Colorado (lane 5), with eight relative EPSPS:ALS gene copies. Similarly, a highly intense EPSPS signal (saturated the film) was observed in lanes 7 and 8 containing GR Palmer amaranth (GR1 and GR2, with approximately 50 and 100 relative copies of the EPSPS gene, respectively) protein extracts, whereas no signal was detected at $48 \mathrm{kDa}$ in lane 6 containing glyphosate-susceptible (SUS-P) Palmer amaranth (one relative copy of EPSPS:ALS gene) protein extract. There is generally a positive correlation

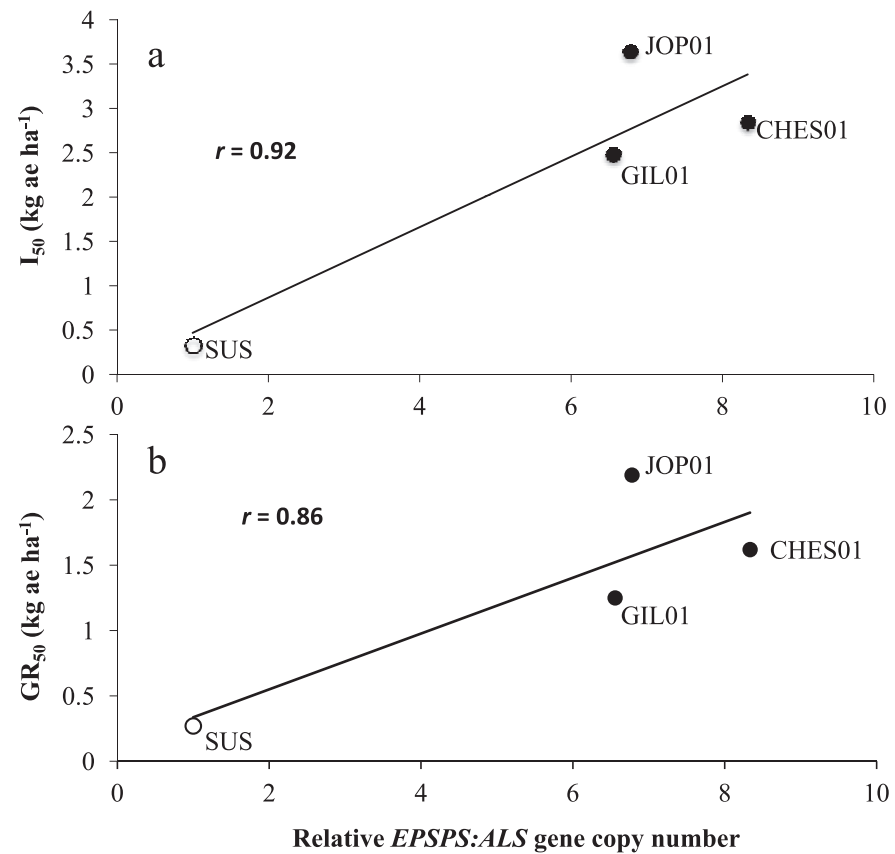

Figure 3. (a) Correlation of relative EPSPS genomic copy number with the amount of glyphosate needed for $50 \%$ control ( $I_{50}$ value) of glyphosate-resistant (JOP01, GIL01, and CHES01) and susceptible (SUS) accessions from Montana. (b) Correlation of relative EPSPS genomic copy number with the amount of glyphosate needed for $50 \%$ shoot dry weight reduction $\left(\mathrm{GR}_{50}\right.$ value) of glyphosate-resistant (JOP01, GIL01, and CHES01) and susceptible (SUS) kochia accessions from Montana. The $I_{50}$ and $\mathrm{GR}_{50}$ values were obtained from the glyphosate dose-response study on the selected accessions (Kumar et al. 2014).

between thicker EPSPS protein bands and higher EPSPS gene copy numbers (Gaines et al. 2010; Wiersma et al. 2015). The qualitative protein assay indicated that GR kochia accessions from Montana with increased EPSPS gene copies accumulated higher EPSPS protein.

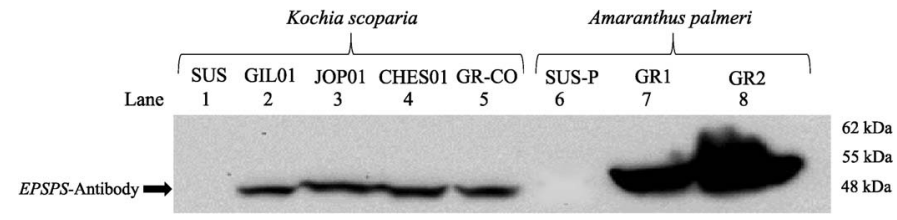

Figure 4. A representative image of nitrocellulose membrance showing EPSPS protein bands probed with anti-EPSPS polyclonal antibody in a western blot. Lane 1, glyphosate-susceptible kochia accession (SUS) from Montana; lanes 2 to 4, glyphosateresistant kochia accessions (GIL01, JOP01, and CHES01, respectively) from Montana; lane 5, GR kochia accession (GR$\mathrm{CO})$ from Colorado (eight copies of EPSPS); lane 6, glyphosatesusceptible (SUS-P) Palmer amaranth accession from Georgia; lane 7 to 8, glyphosate-resistant Palmer amaranth accessions (GR1 and GR2 with $\sim 50$ and 100 copies of EPSPS, respectively) from Georgia. A total of three plants per kochia accession was sampled in each experimental run. 
Table 3. Regression parameters (Equation 1: $D=$ upper limit, $C=$ lower limit, $B=$ slope) for whole-plant dose response based on shoot dry weight $\left(\mathrm{g}_{\text {plant }}{ }^{-1}\right.$ ) of multiple herbicide-resistant (MHR) and susceptible (SUS) kochia accessions from Montana treated with thifensulfuron methyl + tribenuron methyl + metsulfuron. methyl.

\begin{tabular}{|c|c|c|c|c|c|c|}
\hline \multirow[b]{2}{*}{ Accession $^{\mathrm{a}}$} & \multicolumn{4}{|c|}{ Regression parameters $( \pm S E)$} & \multirow[b]{2}{*}{$\mathrm{R} / \mathrm{S}^{\mathrm{c}}$} & \multirow[b]{2}{*}{$\mathrm{GR}_{90}{ }^{\mathrm{b}}$} \\
\hline & $D$ & $C$ & $B$ & $\mathrm{GR}_{50}{ }^{\mathrm{b}}$ & & \\
\hline SUS & $4.24(0.06)$ & $0.14(0.02)$ & $1.8(0.09)$ & $0.003(0.0001)$ & - & $0.01(0.007)$ \\
\hline CHES01 & $3.57(0.06)$ & $0.89(0.03)$ & $0.4(0.07)$ & $0.028(0.001)$ & 9.3 & $2.86(0.35)$ \\
\hline GIL01 & $3.57(0.06)$ & $0.73(0.03)$ & $0.6(0.08)$ & $0.087(0.004)$ & 29 & $3.75(0.39)$ \\
\hline
\end{tabular}

${ }^{a}$ Abbreviations: SUS, susceptible kochia accession, Huntley, MT; GIL01, multiple herbicide-resistant (MHR) kochia accession from Gildford, MT; JOP01, MHR kochia accession from Joplin, MT; CHES01, MHR kochia accession from Chester, MT.

${ }^{\mathrm{b}} \mathrm{GR}_{50}$ is the effective dose ( $\mathrm{kg}$ ai ha ${ }^{-1}$ ) of thifensulfuron methyl + tribenuron methyl + metsulfuron methyl required for $50 \%$ shoot dry weight reduction; $\mathrm{GR}_{90}$ is the effective dose $\left(\mathrm{kg}_{\mathrm{ai}} \mathrm{ha}^{-1}\right)$ of thifensulfuron methyl + tribenuron methyl + metsulfuron methyl required for $90 \%$ shoot dry weight reduction.

${ }^{c} \mathrm{R} / \mathrm{S}$ is calculated as a ratio of $\mathrm{GR}_{50}$ of a MHR accession to $\mathrm{GR}_{50}$ of the SUS kochia accession.

Whole-Plant Dose-Response for ALS-Inhibitor Herbicide. On the basis of shoot dry weight, $\mathrm{GR}_{50}$ values for JOP01, CHES01, and GIL01 MHR kochia accessions were $0.090,0.028$, and $0.087 \mathrm{~kg}$ $\mathrm{ha}^{-1}$, respectively, compared with the $\mathrm{GR}_{50}$ value of $0.003 \mathrm{~kg} \mathrm{ha}^{-1}$ for the SUS accession (Table 3). The R/S ratios (resistance index) indicate that the MHR kochia accessions were 9.3- to 30-fold more resistant to the ALS-inhibitor herbicide premix (thifensulfuron methyl + tribenuron methyl + metsulfuron methyl) compared with the SUS population. Also, the $\mathrm{GR}_{90}$ values of MHR kochia accessions were 159 to 281 times the field-use rate $\left(0.018 \mathrm{~kg}\right.$ ai ha $\left.{ }^{-1}\right)$ of the herbicide (Table 3$)$. This is expected because of continuous use of sulfonylurea herbicides for $>8 \mathrm{yr}$ in dryland wheat-fallow fields in northern Montana from where the MHR kochia accessions were collected. Furthermore, the MHR kochia accessions showed differential response to the ALS-inhibitor herbicide, and the hierarchy of resistance was: JOP01 = GIL01 > CHES01 on the basis of pair-wise $t$-test of the $\mathrm{GR}_{50}$ values (data not shown). Kochia accessions from Kansas reported by Saari et al. (1990) had 12- to 28 -fold levels of resistance to sulfonylurea herbicides. Similarly, Primiani et al. (1990) reported 8to 30-fold levels of resistance to chlorsulfuron, metsulfuron, and sulfometuron herbicides in kochia accessions collected from wheat fields in Kansas. With continued use of sulfonylurea herbicides, there is a widespread occurrence of ALS-inhibitor-resistant kochia in the cereal production regions of the U.S. Great Plains and in Canada (Beckie et al. 2013; Heap 2015).

ALS Gene Sequencing. There was a point mutation causing amino acid substitution at $\mathrm{Pro}_{197}$ residue in the ALS gene sequence $(1,800 \mathrm{bp})$ of MHR kochia accessions (JOP01, CHES01, and GIL01). Compared with the SUS accession with CCG codon at $\mathrm{Pro}_{197}$, there was a change from CCG to CAG codon in all MHR kochia plants (Table 4). This point mutation resulted in an amino acid substitution from $\mathrm{Pro}_{197}$ to $\mathrm{Gln}_{197}$, which conferred high level of resistance (up to 30fold) to the ALS-inhibitor sulfonylurea herbicide tested (Table 3). Although multiple amino acid substitutions ( $\operatorname{Pro}_{197}, \mathrm{Asp}_{376}$, and $\operatorname{Trp}_{574}$ sites) have been reported in ALS-inhibitor-resistant kochia populations (Beckie et al. 2013; Tranel et al. 2015), we did not observe any amino acid substitution at $\mathrm{Asp}_{376}$ or $\operatorname{Trp}_{574}$ position of the $A L S$ gene (almost the entire gene was sequenced) in the tested kochia populations. Among all previously known mutations in ALS gene, substitution of proline at position 197 with threonine, arginine, leucine, glutamine, serine, or alanine is known to confer high level of resistance to sulfonylurea herbicides in kochia (Beckie et al. 2013; Tranel and Wright 2002; Tranel et al. 2015).

In conclusion, this research serves as a first report on the molecular mechanisms of resistance to glyphosate and ALS-inhibitor herbicides in MHR kochia from Montana. There was no mutation found at the Pro $_{106}$ codon of the EPSPS gene, but the MHR kochia accessions had 4 to 10 -fold amplification of the EPSPS gene compared with a single relative EPSPS genomic copy in the SUS accession. MHR kochia plants also accumulated higher EPSPS protein compared with the SUS plants. Substitution of glutamine for proline at position 197 of the $A L S$ gene conferred 9.3- to 30fold levels of resistance to the ALS-inhibitor herbicide in MHR kochia. 
Table 4. Nucleotide bases and derived amino acid sequences of a fragment of $A L S$ gene from susceptible and multiple herbicideresistant kochia accessions from Montana, showing a single nucleotide mutation (bold and underlined codon) at $\operatorname{Pro}_{197}$ residue. $^{a}$

\begin{tabular}{|c|c|c|c|c|c|c|c|c|c|c|c|}
\hline $\begin{array}{l}\text { Reference } A L S \\
\text { gene sequence } \\
\text { of kochia }{ }^{b} \\
\text { Amino acid } \\
\text { positions }\end{array}$ & $\begin{array}{l}\text { ACG } \\
\text { Thr }\end{array}$ & $\begin{array}{l}\text { GGG } \\
\text { Gly }\end{array}$ & $\begin{array}{l}\text { CAG } \\
\text { Gln }\end{array}$ & $\begin{array}{l}\text { GTG } \\
\text { Val }\end{array}$ & $\begin{array}{l}\text { CCG } \\
\text { Pro }\end{array}$ & $\begin{array}{c}\text { CGG } \\
\text { Arg }\end{array}$ & $\begin{array}{c}\text { CGA } \\
\text { Arg }\end{array}$ & $\begin{array}{c}\text { ATG } \\
\text { Met }\end{array}$ & $\begin{array}{l}\text { ATT } \\
\text { Ile }\end{array}$ & $\begin{array}{c}\text { GGG } \\
\text { Gly }\end{array}$ & $\begin{array}{c}\text { ACG } \\
\text { Thr }\end{array}$ \\
\hline SUS1 & ACG & GGG & CAG & GTG & CCG & CGG & CGA & ATG & ATT & GGG & ACG \\
\hline SUS2 & ACG & GGG & CAG & GTG & CCG & CGG & CGA & ATG & ATT & GGG & ACG \\
\hline SUS3 & ACG & GGG & CAG & GTG & CCG & CGG & CGA & ATG & ATT & GGG & ACG \\
\hline JOP011 & ACG & GGG & CAG & GTG & CAG & CGG & CGA & ATG & ATT & GGG & ACG \\
\hline JOP012 & ACG & GGG & CAG & GTG & $\overline{\mathrm{CAG}}$ & CGG & CGA & ATG & ATT & GGG & ACG \\
\hline JOP013 & ACG & GGG & CAG & GTG & $\overline{\mathrm{CAG}}$ & CGG & CGA & ATG & ATT & GGG & ACG \\
\hline GIL011 & ACG & GGG & CAG & GTG & $\overline{\mathrm{CAG}}$ & CGG & CGA & ATG & ATT & GGG & ACG \\
\hline GIL012 & ACG & GGG & CAG & GTG & $\overline{\mathrm{CAG}}$ & CGG & CGA & ATG & ATT & GGG & ACG \\
\hline GIL013 & ACG & GGG & CAG & GTG & $\overline{\mathrm{CAG}}$ & CGG & CGA & ATG & ATT & GGG & ACG \\
\hline CHES011 & ACG & GGG & CAG & GTG & $\overline{\mathrm{CAG}}$ & CGG & CGA & ATG & ATT & GGG & ACG \\
\hline CHES012 & ACG & GGG & CAG & GTG & $\overline{\mathrm{CAG}}$ & CGG & CGA & ATG & ATT & GGG & ACG \\
\hline CHES013 & ACG & GGG & CAG & GTG & $\overline{\mathrm{CAG}}$ & CGG & CGA & ATG & ATT & GGG & ACG \\
\hline
\end{tabular}

${ }^{a}$ Almost the entire $A L S$ gene was sequenced (1,800 base pairs).

b Abbreviations: SUS1, SUS2, and SUS3, three kochia plants from susceptible (SUS) accession; JOP011, JOP012, and JOP013, three kochia plants from multiple herbicide-resistant (MHR) JOP01 accession; GIL011, GIL012, and GIL013, three kochia plants from MHR GIL01 accession; CHES011, CHES012, and CHES013, three kochia plants from MHR CHES01 accession.

Evolution of glyphosate- and ALS-inhibitor MHR kochia in wheat-fallow fields would be a potential concern for growers in the NGP. Wind-mediated tumble mechanism of seed dispersal coupled with pollen-mediated gene flow through outcrossing would ensure rapid spread of MHR kochia. In separate studies, we evaluated the effectiveness of various alternative PRE and POST herbicides to be used for kochia control in wheat, corn/grain sorghum, soybean, chemical-fallow, and postharvest wheat stubble (Kumar et al. 2014; Kumar and Jha 2015a,b). Growers should adopt those effective alternative modes-of-action herbicides and prevent seed production from MHR kochia plants in their production farms. Reduced absorption/translocation and metabolism were ruled out as mechanisms of glyphosate resistance in kochia accessions from Kansas (Waite et al. 2013); however, the possibility of multiple mechanisms of resistance to glyphosate in the selected GR kochia accessions needs to be considered. We are investigating the inheritance pattern of amplified EPSPS gene copies and fitness cost (if any) associated with increase in relative EPSPS gene copies in GR kochia in the presence and absence of glyphosate selection pressure. A random field survey was conducted in 2013 and 2014 to collect kochia populations (approximately 200) from cropland and noncropland areas across north-central Montana. The populations are under investigation for possible multiple resistance to three different herbicide groups (glyphosate, ALS inhibitors, and dicamba) and for determining the frequency and geographical distribution of MHR kochia in Montana. These key research questions will provide insights into the strategies to prevent further spread of MHR kochia in this region.

\section{Acknowledgments}

The authors thank the Montana Wheat and Barley Committee for funding this research. We gratefully acknowledge Merlin Johnson, Shane Leland, and growers from Hill and Liberty counties of Montana for their valuable assistance in kochia seed collection. We are grateful to Dr. Brian Scheffler and Ms. Fanny Liu at the Genomics and Bioinformatics Research Unit, U.S. Department of Agriculture-Agricultural Research Service, Mississippi, for their help in the gene sequencing work, and Dr. Aruna V. Varanasi and Christopher Vanhorn for their technical assistance.

\section{Literature Cited}

Baker DV, Withrow JR, Brown CS, Beck KG (2010) Tumbling: use of diffuse knapweed (Centaurea diffusa) to examine an understudied dispersal mechanism. Invasive Plant Sci Manag 3:301-309 Beckie HJ, Blackshaw RE, Low R, Hall LM, Sauder CA, Martin S, Brandt EN, Shirriff SW (2013) Glyphosate- and acetolactate synthase inhibitor-resistant kochia (Kochia scoparia) in Western Canada. Weed Sci 61:310-318

Bolt MW, Mahoney PA (1997) High-efficiency blotting of proteins of diverse sizes following sodium dodecyl sulfate-polyacrylamide gel electrophoresis. Anal Biochem 247:185-192 
Chandi A, Milla-Lewis SR, Giacomini D, Westra P, Preston C, Jordan DL, York AC, Burton JD, Whitaker JR (2012) Inheritance of evolved glyphosate resistance in a North Carolina Palmer amaranth (Amaranthus palmeri) biotype. Int J Agron DOI: 10.1155/2012/176108

Christoffoleti PJ, Westra PB, Moore F (1997) Growth analysis of sulfonylurea-resistant and -susceptible kochia (Kochia scoparia). Weed Sci 45:691-695

Donald WW, Prato T (1991) Profitable, effective herbicides for planting-time weed control in no-till spring wheat (Triticum aestivum). Weed Sci 39:83-90

Duke SO, Powles SB (2008) Glyphosate: a once-in-a-century herbicide. Pest Manag Sci 64:319-325

Eberlein CV, Fore ZA (1984) Kochia biology. Weeds Today 15:5-6

Forcella F (1985) Spread of kochia in the northwestern United States. Weeds Today 16:4-6

Friesen LF, Beckie HJ, Warwick SI, Van Acker RC (2009) The biology of Canadian weeds. 138. Kochia scoparia (L.) Schrad. Can J Plant Sci 89:141-167

Gaines TA, Zhang W, Wang D, Bukun B, Chisholm ST, Shaner DL, Nissen SJ, Patzoldt WL, Tranel PJ, Culpepper AS, Grey TL, Webster TM, Vencill WK, Sammons RD, Jiang JM, Preston C, Leach JE, Westra P (2010) Gene amplification confers glyphosate resistance in Amaranthus palmeri. Proc Natl Acad Sci USA 107:1029-1034

Giacomini D, Westra P, Ward SM (2014) Impact of genetic background in fitness cost studies: an example from glyphosate-resistant Palmer amaranth. Weed Sci 62:29-37

Heap I (2015) The International Survey of Herbicide Resistant Weeds. http://www.weedscience.org. Accessed January 14, 2015

Knezevic SZ, Streibig JC, Ritz C (2007) Utilizing R software package for dose-response studies: the concept and data analysis. Weed Technol 21:840-848

Kumar V, Jha P (2015a) Effective preemergence and postemergence herbicide programs for kochia control. Weed Technol 29:24-34

Kumar V, Jha P (2015b) Influence of herbicides applied postharvest in wheat stubble on control, fecundity, and progeny fitness of Kochia scoparia in the US Great Plains. Crop Prot 71:144-149

Kumar V, Jha P, Reichard N (2014) Occurrence and characterization of kochia (Kochia scoparia) accessions with resistance to glyphosate in Montana. Weed Technol 28:122-130

Lenssen AW, Waddell J, Johnson GD, Carlson GR (2007) Diversified cropping systems in semiarid Montana: nitrogen use during drought. Soil Tillage Res 94:362-375

Lorentz L, Gaines TA, Nissen SJ, Westra P, Strek HJ, Dehne HW, Ruiz-Santaella JP, Beffa R (2014) Characterization of glyphosate resistance in Amaranthus tuberculatus populations. J Agric Food Chem 62:8134-8142

Mengistu LW, Messersmith CG (2002) Genetic diversity of kochia. Weed Sci 50:498-503

Mohseni-Moghadam M, Schroeder J, Ashigh J (2013) Mechanism of resistance and inheritance in glyphosate-resistant Palmer amaranth (Amaranthus palmeri) populations from New Mexico, USA. Weed Sci 61:517-525

Nandula VK, Reddy KN, Koger CH, Poston DH, Rimando AM, Duke SO, Bond JA, Ribeiro DN (2012) Multiple resistance to glyphosate and pyrithiobac in Palmer amaranth (Amaranthus palmeri) from Mississippi and response to flumiclorac. Weed Sci 60:179-188
Nandula VK, Reddy KN, Poston DH, Rimando AM, Duke SO (2008) Glyphosate tolerance mechanism in Italian ryegrass (Lolium multiflorum) from Mississippi. Weed Sci 56:344-349

Nandula VK, Wright A, Molin W, Ray J, Bond J, Eubank T (2014) EPSPS amplification in glyphosate-resistant spiny amaranth (Amaranthus spinosus): a case of gene transfer via interspecific hybridization from glyphosate-resistant Palmer amaranth (Amaranthus palmeri). Pest Manag Sci 70: 1902-1909

Norsworthy JK, Smith KL, Scott RC, Gbur EE (2007) Consultant perspectives on weed management needs in Arkansas cotton. Weed Technol 21:825-831

Powles SB (2010) Gene amplification delivers glyphosate-resistant weed evolution. Proc Natl Acad Sci USA 107: 955-956

Primiani MM, Cotterman JC, Saari LL (1990) Resistance of Kochia scoparia to sulfonylurea and imidazolinone herbicides. Weed Technol 4:169-172

Ribeiro DN, Pan Z, Duke SO, Nandula VK, Baldwin BS, Shaw DR, Dayan FE (2014) Involvement of facultative apomixis in inheritance of EPSPS gene amplification in glyphosateresistant Amaranthus palmeri. Planta 239:199-212

Saari LL, Cotterman JC, Primiani MM (1990) Mechanism of sulfonylurea herbicide resistance in the broadleaf weed, Kochia scoparia. Plant Physiol 93:55-61

Salas RA, Dayan FE, Pan Z, Watson SB, Dickson JW, Scott RC, Burgos NR (2012) EPSPS gene amplification in glyphosateresistant Italian ryegrass (Lolium perenne ssp. multiflorum) from Arkansas. Pest Manag Sci 68:1223-1230

Sammons DR, Gaines TA (2014) Glyphosate resistance: state of knowledge. Pest Manag Sci 70:1367-1377

Sathasivan K, Haughn GW, Murai N (1990) Nucleotide sequence of a mutant acetolactate synthase gene from imidazolinone-resistant Arabidopsis thaliana var. Columbia. Nucleic Acids Res 18:2188

Schwinghamer TD, Van Acker RC (2008) Emergence timing and persistence of kochia (Kochia Scoparia). Weed Sci 56:37-41

Seefeldt SS, Jensen JE, Fuerst EP (1995) Log-logistic analysis of herbicide dose-response relationships. Weed Technol 9:218-227

Shaner DL, Nadler-Hassar T, Henry WB, Koger CH (2005) A rapid in vivo shikimate accumulation assay with excised leaf discs. Weed Sci 53:769-774

Singh BJ, Shaner DL (1998) Rapid determination of glyphosate injury to plants and identification of glyphosate-resistant plants. Weed Technol 12:527-530

Sivakumaran K, Mulugeta D, Fay PK, Dyer WE (1993) Differential herbicide response among sulfonylurea-resistant Kochia scoparia L. accessions. Weed Sci 41:159-165

Stallings GP, Thill DC, Mallory-Smith CA, Shafii B (1995) Pollen-mediated gene flow of sulfonylurea-resistant kochia (Kochia scoparia). Weed Sci 43:95-102

Tranel PJ, Riggins CW, Bell MS, Hager AG (2011) Herbicide resistance in Amaranthus tuberculatus: a call for new options. Pest Manag Sci 59:5808-5812

Tranel PJ, Wright TR (2002) Resistance of weeds to ALSinhibiting herbicides: what have we learned? Weed Sci 50:700-712

Tranel PJ, Wright TR, Heap IM (2015) Mutations in herbicideresistant weeds to ALS inhibitors. http://www.weedscience.org. Accessed January 7, 2015

Waite J, Thompson CR, Peterson DE, Currie RS, Olson BLS, Stahlman PW, Khatib KA (2013) Differential kochia (Kochia 
scoparia) populations response to glyphosate. Weed Sci 61:193-200

Warwick SI, Xu R, Sauder C, Beckie HJ (2008) Acetolactate synthase target-site mutations and single nucleotide polymorphism genotyping in ALS-resistant kochia (Kochia scoparia). Weed Sci 56:797-806

Wiersma AT, Gaines TA, Preston C, Hamilton JP, Giacomini D, Buell CR, Leach JE, Westra P (2015) Gene amplification of 5-enol-pyruvylshikimate-3-phosphate synthase in glyphosateresistant Kochia scoparia. Planta 241:463-474
Yu Q, Jalaludin A, Han H, Chen M, Sammons RD, Powles SB (2015) Evolution of double amino acid substitution in the EPSP synthase in Eleusine indica conferring high level glyphosate resistance. Plant Physiol DOI: 10.1104/pp.15. 00146

Received February 4, 2015, and approved April 20, 2015.

Associate Editor for this paper: Franck E. Dayan, USDAARS-NPURU. 